\title{
Decolonisation and renewed racism: A challenge and opportunity for reconciliation?
}

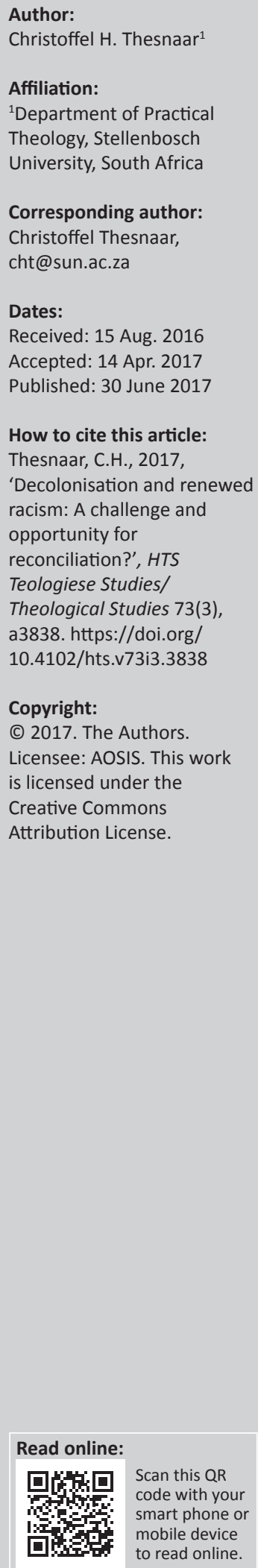

The university campuses across South Africa have recently been challenged by significant student protests concerning issues such as the abolishment of study fees, aspects of decolonisation and language policies, to name but a few. This contribution will briefly reflect on these challenges by engaging with the narrative of decolonisation. An area of particular focus is whether reconciliation is still relevant within the current South African context, given the nature of the issues driving the university protests. This contribution will attempt to provide some recommendation for public theologians to engage with these challenges in a responsible way in their endeavour to be advocates for sustainable peace and reconciliation.

\section{Introduction}

South Africans have become all too familiar with the recent service delivery protests by mainly poor black citizens. Most of these protests have been directed at local government as the level of disillusionment, frustration and disappointment regarding un-kept promises (TRC 1998) ${ }^{1}$ has at times culminated in violence. This view is echoed by Archbishop Makgoba (2016) when he states:

For decades, the promises of equality haven't been kept. The promise of equality, of opportunity has failed to be delivered or achieved. We can't just feel and preach. We want more than just talk - we want action. (p. 5)

The service delivery protest action soon culminated in acts of violence that eventually spilled over into townships and university campuses as desperation grew concerning the continuation of social inequality and exclusion within a post-transitional society, as people realised they have nothing to lose (see Mbembe 2016:1).

The protest action by university students started with the Black pain matters - \#Rhodesmustfall ${ }^{2}$ campaign, which manifested in strong and even violent reactions against, firstly, the statue of Cecil John Rhodes, as it represented everything colonialism stood for, and subsequently, this action spread to all other statues on campuses throughout the country. Decolonisation became part of a strong narrative raised by the protesting students in their struggle to be heard. The momentum from the \#Rhodesmustfall action grew rapidly into the \#Feesmustfall and rape culture campaign that subsequently spread to all campuses. ${ }^{3}$ Hofmeyr and Govender (2015:2) commented in their report that apart from these actions, another strong significant refrain developed, which challenged the core of the liberation and transition process by the current generation, namely: 'We were sold out by Mandela'. There has also recently been a significant increase in blatant racist expositions by white and black citizens of our country on social media and in public places, which create the impression that it has been boiling under the surface for some time and just needed the current context to erupt. ${ }^{4}$ The motivation behind this contribution is to understand how Public theologians ${ }^{5}$ should engage these deep-seated issues within our society.

This article will briefly reflect on some of the core challenges and opportunities facing reconciliation within a context of decolonisation, injustices on many levels and deep-rooted racism, within the

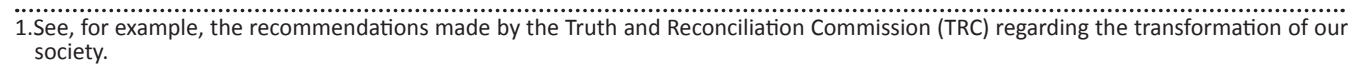

3.In most cases, the student protest actions also carried the plea of the staff from outsourcing companies contracted by universities, who are not treated and paid fairly by these companies.

4.See the article by Msomi and Shilaho (2008) on 'Racism Still a Threat to South Africa's Democracy' on the website of the Centre for the Study of Violence and Reconciliation; and the article by Jansen (2015) on 'Racism on Campus: Jumping around "like Mad Hatters",

5.See Smit (2008:28-31) on the definition of a Public theologian. In this context, public theologians also include church leaders on al levels of the church society. 
current South African society. From this discussion, the article attempts to engage with the question of whether reconciliation is still relevant within the current South African context. The article will conclude with a few challenges and recommendations for Public theologians to adhere to in their endeavour towards reconciliation.

\section{Towards an understanding of the current context}

In an attempt to understand the amount of anger and frustration that manifested during the student protest action as well as the increase in blatant racism incidents in our society, I came across an article by the Zimbabwean scholar Ndlovu-Gatsheni (2014), who proposed a helpful perspective to understand and interpret this current complex and challenging situation in our country. Ndlovu-Gatsheni (2014:34) explains that the strong narrative of decolonisation ${ }^{6}$ has become the driving force of young people as they strive for justice, restitution and transformation. This narrative of decolonisation actually represents the depth of the reaction against the power of racist imperial colonists who for centuries were responsible for the dehumanisation of black Africans on the continent. This reaction was based on the premise that colonialists were not interested in treating indigenous Africans with dignity and respect but instead, their intentions were to gain as much as possible from the people, including resources and the continent. ${ }^{7}$ Gerard Gaylard (2005:60) affirms this when he states that '... the West had a profoundly exploitative relationship with the continent and has deemed its denizens to be inherently inferior in race'. Thus, when the African countries gained their independence during the previous century, the assumption could easily be made that it finally would bring an end to colonialism. However, the contrary is actually true; as the majority of African countries are to a large extend still dependent on the countries with a greater economic and political power.

Ndlovu-Gatsheni (2014:35) defines this dependency as coloniality and explains that Eurocentrism ${ }^{8}$ '... gave birth to coloniality'. Maldonado-Torres (2007, in Ndlovu-Gatsheni 2014:35) indicates that coloniality should be understood ' ... as a global imperial power structure that survived the end of direct administrative colonialism'. This structure managed to exist far beyond the limits of colonial administrations by keeping long-standing patterns of power intact, which determined how culture, labour, intersubjective relations and knowledge production should be defined and understood. ${ }^{9}$

6.Mbembe (2016:1) defines decolonisation as "For the time being, it goes by the name
"decolonization" - in truth a psychic state more than a political project in the strict "decolonization" - in
sense of the term'.

7.In this regard, see the 1991 classic book by Pakenham, The scramble for Africa.

8.Amin (2009:179, in Ndlovu-Gatsheni 2014:37) added that Eurocentrism is 'expressed in the most varied of areas: day-to-day relationships between individuals, political formations and opinion, general views concerning society and culture, social science'.

9.This is why all these initiatives are taking place within a modern global order governed by what David Slater terms 'imperiality of knowledge' (Slater 2004, in governed by what David Slater terms 'imperiality of knowledge' (Slater 2004, in Ndlovu-Gatsheni 2014:35). The role of 'imperiality of know is that while concedes to the ideas of difference, it does not concede to the right of peoples of the Global South and their leaders to negotiate their own conditions of discursive control, to practice its difference in the interventionist sense of rebellion and disturbance' (Richard 1995:211, in Ndlovu-Gatsheni 2014:35).
In an endeavour to understand this quest, it simply cannot be limited to an argument based on the premise that it did exist. As echoed by the students in the protests, it still exists and is kept alive by the powers of our institutions through their lack of transformation, as well as in academic publications, the criteria for academic performance and access to tertiary education. This ongoing and prevailing manifestation of coloniality is an affirmation of deep-rooted and ongoing racism and is coherent with what Mbembe (2015:28) signals as continuously new configurations of racism that is emerging worldwide.

It seems this quest is not only limited to certain aspects of our society such as government and the social society at large but also dissects deeply into the religious society. In this regard, Ndlovu-Gatsheni (2014:35) states that this should be understood as '... a reality and continues to affirm super human beings even ordained by God and history to dominate and exploit other human beings'. Ndlovu-Gatsheni (2014:36) further explains that through these actions Euro-North American epistemology has been globalised, but African minds have been colonised, making it very difficult for Africans to exercise extra-structural agency. Mbembe (2016) calls this mindset of the Euro-North racist and states the profound effect on black people as follows:

Part of what racism has always tried to do is to damage its victims' capacity to help themselves. For instance, racism has encouraged its victims to perceive themselves as powerless, that is, as victims even when they were actively engaged in myriad acts of self-assertion. (p. 8)

These myriad acts of self-assertion were evident when the on-campus protest actions shifted in intensity and purpose as it became '... more urgent and uncompromising and, importantly, less patient with anything or anyone appearing to stand in the way of more radical forms of social transformation' (Hofmeyr \& Govender 2015:3). Mbembe (2016:3) indicates that some of the reasons for this change in intensity and purpose are that the lives of black South Africans continue to be negated by structures that maintain and support 'white power and supremacy' 20 years after liberation. According to Mbembe (2016:3), these structures urgently need to be disrupted and brought to an end by any means possible, even by violence. He not only helps us to place coloniality into context but also indicates that the other strong narrative against 'whiteness', 'white power', 'white supremacy' and 'white monopoly capital' is firmly placed back on the political and cultural agenda by the so-called; 'born-free' generation. ${ }^{10}$

Although protest action and a strong focus against whiteness is not something new in the history of our country, there tends to be a shift in the way the born-free generation acts and engages in the society today. Sekgabo Motshwane (Talane 2012:1) indicates in his testimony as a 'born-free' South African that he acknowledges the importance of remembering the struggle, but his focus is on the future. This was evident 10.'Born frees' is commonly referred to as those South Africans born in the year of or after the country's first free elections (Collins English Dictionary 2016). 
in the encounters between the management and the 'bornfree' students as it soon became very clear that there was a strong shift towards their own struggles over against the struggles of the liberation heroes (who are currently more and more represented in management). Msimang (2015) describes the current generation as the champions of freedom and then at the same time cautions the liberation generations that their time has elapsed to change and transform this country:

Your role in the revolution will not save you. Your history of speech-making and sleeping in a cold detention cell will not save you. Not even back-breaking labour on Robben Island will spare you the scepticism of today's champions of freedom. (p. 1)

They are not interested and willing to listen to anybody apart from their own struggles. They see themselves as the generation that has the authority to transform society. ${ }^{11}$

In this regard, my assumption of the on-campus protests is that students strive to control the agenda of all engagements as they do not trust the authorities; but they are loath to any type of discussion because no one will understand their pain and suffering unless they have gone through it themselves. Mbembe (2016:2) describes this as, 'Psychic bonds - in particular bonds of pain and bonds of suffering more than lived material contradictions are becoming the real stuff of political inter-subjectivity' and the 'fusion of self and suffering in this astonishing age of solipsism and narcissism'.

\section{Is reconciliation still relevant within the context of South Africa today?}

The shift in intensity and purpose towards the campuses has really challenged the heart of the transition in South Africa, as Hofmeyr and Govender (2015) explain:

When many within the current student movement therefore retrospectively charge Mandela with 'selling out', they use concessions made to the apartheid government at the Convention for a Democratic South Africa (CODESA), prior to the 1994 elections, as an economic reference point, while 'reconciliation' and the broader work of the TRC are blamed for the continued exclusionary dominance of white values and racism. Reconciliation, for those who still attach any value to it within the student movement, can only redeem itself under conditions in which economic justice prevails. (p. 3)

Mbembe (2016) affirms this when he states:

Rainbowism and its most important articles of faith - truth, reconciliation and forgiveness - is fading. Reduced to a totemic commodity figure mostly destined to assuage whites' fears, Nelson Mandela himself is on trial. Some of the key pillars of the 1994 dispensation - a constitutional democracy, a market society, non-racialism - are also under scrutiny. (p. 3)

Indeed, it does seem that reconciliation (as concept and process) has lost its prominence in South Africa, and

11.Although Hofmeyr and Govender (2015:5) in their research acknowledge this reality, it does question whether such a generational split is also evident in the way that South Africans from different age categories view reconciliation. therefore, it raises the question about the relevancy of reconciliation not only as a concept but also as a process.

The research published by the Institute for Justice and Reconciliation (IJR $)^{12}$ in 2015 reveals that most South Africans still agree that the creation of a united, reconciled nation $(71 \%)$ remains a worthy objective to pursue. It also indicates that South Africans generally believe that the country has made progress regarding national reconciliation since the end of apartheid (59.2\%) and are convinced that the country should continue to pursue it as a national objective (69.7\%). Although this is certainly a very positive indication, the IJR research (Hofmeyr \& Govender 2015:7) also clearly states that most South Africans agree that reconciliation will continue to be under pressure while the majority of this nation are still impoverished and economically excluded. Therefore, it is understandable that the new generation will not tolerate any form of reconciliation without eliminating all forms of injustices. Although Dr Mohammed ElBaradei (2015:1) reminds us that mounting inequality is a worldwide problem, the fact that it is not sustainable has according to Hofmeyr and Govender (2015:7), '... considerable implications in a country that routinely vies for the inglorious honour of being the world's most unequal nation'.

From the research published by IJR, it seems that the majority of citizens are still in support of continuous processes of reconciliation. However, it has become more and more evident that this is not possible without addressing past and present injustices related to the Apartheid Era. There is thus a need to search for renewed perspectives that can assist South Africans to regain the impetus to strive for a just society in order to reach sustainable peace and reconciliation. Decolonisation is one possible perspective that can be used to reach this goal as it endeavours to change the continued power ${ }^{13}$ of Western governance. Wa Said (1971:503), writing as someone who experienced colonialism first hand, already indicated as long ago as 1971 that the only way to end colonialism is to decolonise politically and economically. Tuck and Yang (2012:3) caution us not to understand decolonisation as a metaphor, as it destroys the idea of what decolonisation actually is. To elucidate, the terms 'decolonise' (a verb) and 'decolonisation' (a noun) are to be aware that our pre-existing frameworks will limit us to understand the scope of these terms (Tuck \& Yang 2012:3). In this regard, Chen (2010:3, in Ndlovu-Gatsheni 2014) explains:

Decolonization did not simply mean modes of anti-colonialism that were expressed mainly through the building of a sovereign nation-state, but also an attempt by the previously colonized to reflectively work out a historical relation with the former colonizer, culturally, politically, and economically. This can be a

12. Hofmeyr and Govender (2015:16) state that as in previous years, we would like to caution that these findings do not suggest that either income or race has become the definitive source of division in South Africa because they largely overlap. Rather, the findings' significance lies in which aspects of daily life are foremost in the minds of respondents when they observe society and in particular, the cleavages they perceive therein (cf. Hofmeyr \& Govender 2015).

13.The reality is that since 1492, Europe and North America gained a long-lasting victory: not only through the force of its weapons: it remains so through its 'models' of growth and development, through the statist and other structures 'models' of growth and development, through the statist and other structures
which having been created by it, are today adopted everywhere. (Castoriadis which having been created by it, are
1991:200, in Ndlovu-Gatsheni 2014:35) 
painful process involving the practice of self-critique, selfnegation, and self-rediscovery, but the desire to form a less coerced and more reflexive and dignified subjectivity necessitates it. (p. 35)

Since the completion of the work of the Truth and Reconciliation Commission (TRC), there has not been any significant attempt to actively facilitate a process, despite how painful, whereby the previously colonised could reflectively work out a historical relation with the former coloniser in terms of culture, politics and economics.

For this relation to take place, Ndlovu-Gatsheni (2014:38) adds a second perspective that actually calls for simultaneous action of decolonisation and deimperialisation to portend a global future of genuine democracy. According to him, 'Deimperialization is also a more encompassing category and a powerful tool with which we can critically examine the larger historical impact of imperialism' (Ndlovu-Gatsheni 2013:349). To him, deimperialisation is a task that can only be performed by the former colonisers themselves as it involves a genuine examination of the conduct, motives, desires and consequences of the imperialist history. Wa Said (1971) already proposed this action in 1971 when he stated that:

Theology of Decolonization calls for reconciliation between races in accordance with the teachings of Jesus Christ. But such reconciliation is not the work of the oppressed, because, historically, he has already played his part for some 529 years, loving, forgiving, serving, and even dying for the oppressor. It is the duty of the oppressor to take the initiative, to take the first step towards such reconciliation. (p. 515)

Practically, this entails that Western countries (Europe and North America) should take collective responsibility for their role and actions as colonisers. Taking responsibility is more than just to abandon their arrogant attitude against nonWestern countries as it invokes feelings that they cannot do anything on their own and therefore need to be taught and guided by them. It is fundamentally about taking responsibility to engage with African countries on complex issues such as restitution and transformative justice. Since the completion of the work of the TRC, there has not been any significant attempt or action by the colonisers to take collective responsibility for any injustices that was done during the colonial past neither was there any attempt to engage in discussions nor to participate in processes of restoration and restitution.

A third possible perspective to change the continued power of Western governance and work towards sustainable peace and reconciliation is what Tuck and Yang (2012:31) call, incommensurability. According to Memmi (1991, in Tuck \& Yang 2012:31), the goal of incommensurability is to break the relentless structuring of the colonial triad without any compromise. Although breaking the colonial triad could entail repatriating land, abolishing cheap labour and dismantling of imperial parent structures with colonies, decolonisation is not equivocal to other anti-colonial struggles, and therefore, it is incommensurable (Tuck \& Yang
2012:31). In their argument, Tuck and Yang (2013:35) clearly indicate the dangers of misunderstanding reconciliation as a process of rescuing the colonisers from indigenous groups during a transition process. According to them, 'to fully enact an ethic of incommensurability means relinquishing settler futurity, abandoning the hope that settlers may one day be commensurable to Native peoples' (Tuck \& Yang 2013:36). They further also warn against a simplistic approach to break the triad where indigenous people take positions of dominance over white settlers; 'the goal is not for everyone to merely swap spots on the settler-colonial triad, to take another turn on the merry-go-round' (Tuck \& Yang 2012:31). This will also not assist in changing the continued power of Western governance and neither will it contribute towards sustainable peace and reconciliation for generations to come.

\section{How should we respond theologically?}

The perspectives from Ndlovu-Gatsheni (2014) and Tuck and Yang (2013) are indeed helpful direction indicators in the quest to find ways to deal with the current challenges and opportunities regarding reconciliation. Public theologians should especially not underestimate these indicators when engaging in the discourse on reconciliation. The lack of redistributive justice, restitution, deep social polarisation, dehumanisation of black people, growing inequality and our inability to attempt to resolve these issues, since the transition in 1994, has all but exposed and deconstructed all romantic, simplistic, popular or idealistic understandings of the concept of reconciliation.

During the time of the first democratic election in South Africa as well as during the TRC process, there was a strong emphasis on reconciliation that was strongly portrayed by iconic figures such as former state president Nelson Mandela and Emeritus Archbishop Desmond Tutu. This emphasis on reconciliation was nationally supported by religious, civil and government sectors. It was also internationally acknowledged and even acclaimed as an example of real reconciliation for the world to take cognizance of. The emphasis that was put on South Africans to reconcile was indeed based on a very sincere belief that reconciliation will take our country beyond its traumatic past. In retrospect, the assumption could be made that the aura at the time and the way reconciliation was portrayed after the completion of the TRC process created the impression that it was based on a romantic, simplistic, popular and idealistic understanding of reconciliation and unity.

In this context, Eddy van der Borght ${ }^{14}$ (2015:426) rightly asks what the specific contribution of Christian theology can be in a new context when the concept of reconciliation has been transformed from a theological term used in religious communities to a term broadly used in the public domain. This is indeed a significant question as it challenges Christian theology not to get caught in a simplistic understanding of reconciliation and transformation but to really fundamentally interpret their conviction, that healing, sustainable peace and 14.Desmond Tutu Chair in Theology at the Free University in Amsterdam. 
unity can be achieved, within the larger process of reconciliation. It also calls for Christian theology to understand and interpret that the current emphasis on decolonisation, land and economic restitution has opened a wound exposing deep-seated racism that is a clear indication of the lack of reconciliation within churches and in society. ${ }^{15}$ It furthermore serves as a warning to not get stuck in traditional processes of reconciliation as they are limited in the current context. In this regard, Mohammed ElBaradei (2015:1) emphasises, in relation to the continuous challenges by the Islamic State, that we should be cognizant that traditional approaches employed to achieve unity and reconciliation in our society will not necessarily be effective in the future as it will continuously be challenged.

In terms of the discussion thus far, Public theologians will need to continuously grapple with the way they engage with the process of reconciliation especially with regards to the manifestation of complex issues such as deep-rooted racism that was ignited by the extend of the decolonisation narrative. Therefore, Public theologians need to continuously engage with the decolonisation action in order to understand and interpret it within Christian theology and the process of reconciliation. In order to ensure that Public theologians take up this challenge and opportunity, this contribution wants to propose a few recommendations in this regard:

- Public theologians should refrain from dealing with complex issues such as restitution, economic justice and racism, to name a few in the form of public statements and/or declarations as this is more than often experienced as arrogant. When the Belgian Bishops wrote and published a letter on racism in 1995 ('Migrants and refugees in our midden'), some antiracism organisations were in support, while some church members reacted with incomprehension and even rejection. Public statements by religious leaders indicating that racism is a $\sin$ have the potential to aggravate racism among its members even further. In this sense, reactions varied from total support (usually from those outside the church) to intense aggravation and/or anger. Although a strong statement of principle against racism and racists is important, many people struggling with racism either based on the past, or fear of the unknown or of the 'other', felt that their views were inadequately understood and acknowledged in this letter by the church. Respectively, a letter or statement by any religious community on an issue such as racism can never comprehend the injustice of racism as well as the injuries it has caused and continues to cause. Even though particular white church leaders can support and defend such statements, ${ }^{16}$ it is evident that they are not able to fully grasp the impact of racism and the suffering inflicted on fellow South Africans.

15.According to Hofmeyr and Govender (2015): : ... about one in three people did not believe that it was difficult to confront someone they knew when he or she spoke or behaved in a racist manner. The corresponding figure for incidences involvin or behaved in a racist manner. The corresponding figure for incidences involving strangers is about one in five people. This suggests that there do exist challenges to such racist speech and behaviour by ordinary South Africans in their daily lives and succour for the future when we can hope to reduce such speech and behaviour succour for the future when we can hope
significantly and even eliminate it' (p. 12)

16.Translated from the Afrikaans text.
It becomes problematic when the Public theologians continue to disregard the complexities of issues such as racism, racial violence, injustices and colonialism in our society, and thereby, attempt to minimise the impact it has on people's lives as this will just lead to more aggravation and anger. In this regard, Dr Mohammed ElBaradei (2015:1) reminds us that the reason why people become radicalised to the extent that we are experiencing today is because of years and years of poverty, lack of dignity and oppression.

- Public theologians should refrain from moralising deeprooted and complex issues in our society, such as restitution, economic justice and racism. Public theologians should refrain from always being too enthusiastic and quick to take a moral position on a complex issue without listening to and understanding the consequences of the issue at hand. Moralising, for example, racism has the potential to become counterproductive to the initial goal it sought to achieve. By moralising racism Public theologians can easily fall prey to the tendency to condemn, alienate and accuse those specific individuals who are blatantly racist without any awareness and acknowledgement of their own racism. Accusing others or specific individuals of being a racist is to deny one's own ability to be a racist and to defend oneself in this regard. ${ }^{17}$ This was particularly evident during the time of the $\mathrm{TRC}^{18}$ when certain white perpetrators were identified and depicted as prime evil, based on a moral theology of what they did to others. This was mainly done by the white religious community, without acknowledging their own responsibility towards oppressing others during Apartheid or being racists themselves. The reality is that within a purely moral approach, racists will never give up or change their selfprotective mechanisms to justify being racist if they are shamed or sidelined. Some racists have a real fear of the unknown and of 'the other'. When therefore dealing with these complex issues, it is of utmost importance that Public theologians should be united in the way they deal with complex issues such as racism, but it should also not relieve those within their constituency who are struggling to deal with these complex issues in our society. Or more concretely, it should in no uncertain terms reject racism, but never the people who practice racism.

- Denominational Apartheid on the grounds of race should no longer be tolerated by Public theologians as it contributes to colonial segregation, injustices and racism. Members of these denominations remain in their enclaves of segregated and racial comfort with limited contact with the 'other' and with restricted integration in social and community settings. Hofmeyr and Govender (2015:7) affirm this in their research as they indicate that most interracial interaction between South Africans are limited to an engagement in public spaces. These include places where people work and study together and shopping

17.See Pollyfeit (1996) in terms of how perpetrators tend to defend themselves of atrocities done to others.

18.The TRC was set up to assist South Africans to deal with its apartheid past after the transition to democracy. It began in 1996 and ended in 1998. 
centres. Whereas interaction in more intimate spaces, such as private homes and social or communal gatherings, is limited for the majority of our society. Hofmeyr and Govender (2015:7) indicate in their research that citizens who are materially better off report higher levels of interracial interaction than those who are worse off. In terms of the context of the church, Van der Borght (2015:426) alludes to the Emeritus Archbishop Tutu who often refers to a Sunday morning service as the most divided space in our country. The continuation of this division, given our history, will result in developing racists for generations to come, as the insidious poison being carried from one generation to the next will subsequently destroy our society. Racism will therefore continue regardless of the economic or political situation of people. The challenge for Public theologians is to contribute towards breaking the cycle of generational racism that we still encounter in our society today.

Public theologians should endeavour on the journey to build and establish trust at all levels of our society. Hofmeyr and Govender (2015:15) affirm this in their research as they indicate that after the transition, the trust between South Africa's historically defined racial categories remains critically low. ${ }^{19}$ This is echoed by Archbishop Thabo Makgoba (2016) during the launch of a national conversation on the Socio-Economic Future of South Africa (SEFSA), where he states:

Our nation is experiencing an unprecedented and historic crisis of distrust. Industry doesn't trust government. Labour doesn't trust government. Civil society doesn't trust government. Traditional leaders and religious leaders don't trust government. International banks and markets don't trust government. And in response, government says, it doesn't trust anyone either. In fact, I believe the most endangered species in South Africa is not what you think it is. It is trust. (p. 3)

- This corresponds with the earlier discussion that students do not trust management or government; neither do management or government trust the students during the recent protest action. Dr Mohammed ElBaradei refers to the impact of distrust within a society as a cancer. The cancer of distrust has crept into our society despite the efforts of the TRC and other processes, as people remain aloof from one another. It has become more and more evident that we are seeing less and less tolerance and a greater disregard for the otherness of human beings. One way of addressing this is to create safe spaces for trust building within our religious communities where, firstly, members who struggle with racism can honestly engage with their struggles, communicate their fears and be heard. Then, secondly, we need to create safe spaces within our communities where human beings from all sides of the spectrum can be afforded the opportunity to engage with one another, listen to each other, voice their fears and anxieties, journey together and be open to each other's humanity, fragility and challenges. Thirdly, religious communities should also create spaces for members of different faiths to engage with one another in order to

19.See the statistics presented by Hofmeyr and Govender (2015:15) in this regard. generate interreligious trust. What is undeniably true is that we need the 'other' to be human and to build trust. What is humbling is that Wa Said (1971:519) already proposed in 1971 that a theology of Decolonisation as a theology for those who are inferior and oppressed always leaves room for the oppressor. This is why he strongly states that a theology of decolonisation is prepared to fight and destroy those systems of evil by all means necessary in order to free both the oppressed and the oppressor (Wa Said 1971:519). Mbembe (2016:8) affirms the importance of the other when he reflects on the danger that the experience of the self becomes the only way forward in terms of how black Africans are dealing with white power:

The self is made at the point of encounter with an Other. There is no self that is limited to itself. The Other is our origin by definition. What makes us human is our capacity to share our condition - including our wounds and injuries - with others. (p. 8)

Greater social cohesion can be attained when people respect each other's humanity and dignity. Trust is born when we start to hear the human factor in people. The religious community can become a respected trust builder only when it is able to be humble and show its own brokenness and vulnerability. In this regard, Wa Said (1971:523) already stated in 1971 that this is why a theology of Decolonisation wants to see more of humanity in capitalism, more of humanity in communism, more of humanity in socialism and more of humanity in any other 'isms' (such as neo-colonialism, imperialism, Christianism, etc.); or these in-human systems must be destroyed once and for all.

- To deal with these complex issues such as restitution, economic justice and racism is a multilayered problem that needs a multilayered approach requiring Public theologians to take responsibility to address and deal with the core issues contributing to, for example, racism. Wa Said (1971:515) already noted in 1971 that white Christians do not take any responsibilities for the causes that make black people suffer. Taking responsibility in this modern day and age will notably entail an active and comprehensive approach to address the influencing factors causing anxiety and racism such as poverty, unemployment, insecurity, threat of violence, corruption, economic injustices, environmental degradation, spiritual hopelessness, etc. Taking responsibility to actively participate in processes of decolonising our society entails that Public theologians should become advocates for transformative justice, restitution and reparation as it is key for decolonisation and is essentially part of the process of reconciliation. Public theologians cannot continue to accept the growing gap between the rich and poor, as well as the growing inadequacy of systems such as the service delivery or education systems; neither can it distance itself from actively engaging with decolonisation.

- Owing to the complex and multifaceted nature of complex issues in our society, Public theologians should not solely endeavour to deal with these issues, for example, 
combatting racism on its own. Instead, it should immerse itself in ecumenical, interfaith and civil society actions to deal with these issues. As indicated, the key aspect is not whether Public theologians should get involved but how it should get involved. It should not try to provide answers or give advice in a condescending way but it should be humble and vulnerable in its engagement with society. Archbishop Thabo Makgoba (2016:2) demonstrates the vulnerability of his own church when it comes to interacting with the challenges of society, 'I cannot speak for any but my own church, but we too have our own internal crises over corruption and power struggles'. With regards to the context of Public theologians, it needs to be cognizant of the biased position from which it emerges when it engages with the other or with the South African society. So many churches are still influenced by how white colonial clergy interpret the Bible within society and the perspectives they bring into the discussions via preaching and ministry. ${ }^{20}$ The church should be aware and sensitive to white colonial power and privilege and how this limits our vision and ability to understand the 'other'. An example of where the church fraternity should get involved is in the national conversation on the SEFSA. SEFSA is an initiative that is created and driven by civil society and strongly directed by social, economic, spiritual and cultural imperatives (Makgoba 2016:5). The motivation behind this initiative is to endeavour, to create a broad national platform for future and ongoing consultation and consensus building with the aim to find agreement on the challenges we as South Africans are facing and to find means and mobilise action in order to address them. The objectives of this initiative are to:

1. Rebuild hope and confidence among South Africans.

2. Recover our vision and create a growing economy.

3. Renew the soul of our nation and build a united, prosperous and healed South Africa (Makgoba 2016:5).

In order to reach these objectives, the initiative is based in no uncertain way on constructive and transformative principles as Makgoba (2016) states:

Our social compact was premised on certain principles that we all must accept as binding, including the transformation of our entire economic, social, cultural, political and spiritual framework. We need to retool, restructure, rebuild and reconcile so that we create a society that is just, socially stable, compassionate, fiscally prudent, culturally conscious, spiritually grounded, culturally cohesive and economically sustainable. (p. 4)

- Public theologians need to actively participate in decolonising our theological content ${ }^{21}$ and develop an inclusive theological language. Snyman (2014b:5) indicated within the context of the hope and reconciliation process in the Worcester community (see Snyman 2014a), the one thing that unites people is how

20.Se the contribution of Wa Said (1971:508-510) in this regard.

21.See the contribution of Wa Said (1971:520-524) in this regard. 'religious' people are, but the quality of theological thinking is very simplistic. The religious society needs to be able to assist people with the theological 'tools' to continue and endure on the journey of reconciliation. There is a lot of thinking around reconciliation happening in other disciplines that can enrich theological thinking. Public theologians need to decolonise our theological language and take part in developing a new language. The theological content cannot limit our theology to proclaim and confess a God who judges and condemns, and thereby, induces fear in people, but we should find new ways to re-tell the story and symbolise a healing and merciful God of grace and faithfulness. Therefore, when it engages with society, as van der Borght (2015:426) proposes, it should offer forgiveness and reconciliation (with the focus on the potential for reconciliation in all contexts); however, it should not only propose a theological content of forgiveness and reconciliation, but demonstrate it as well.

\section{Conclusion}

Even though most South Africans desire to live in a united, reconciled South Africa, the historical legacy of colonialism and imperialism as well as the structural legacy of apartheid continue to reinforce old patterns of racism, dehumanisation, white power and prejudice. These patterns are still evident in the injustices we face within our society such as economic, education and land injustices, to name a few. These injustices have recently been highlighted by the on-campus university protests, especially regarding the issues of decolonisation, coloniality, deimperialisation, tuition and transformation at universities, racism and reconciliation, to name a few.

To develop an understanding of the challenges and injustices facing our society, the contribution by Ndlovu-Gatsheni (2014), as mentioned earlier, is especially helpful to assist all South Africans to become aware of how knowledge systems influence the web of meaning in our society. In order to address these knowledge systems in a constructive way, this contribution reflected on the narrative of decolonisation as an avenue to deal with the captivity of these webs and offer a way to break the webs created by our past. In this regard, Tuck and Yang (2013:35) rightfully state, 'Decolonization is not an "and." It is an elsewhere'.

In an attempt to break these webs, South Africans in general, and Public theologians in particular, are challenged to rewrite the epistemologies that support and maintain the injustices of the past into epistemologies of transformative justice that has the ability to create hope for all its citizens. In order to achieve this, Public theologians should participate not only to develop theologies of liberation but to emphasise a belief that these theologies should indeed be liberative. Developing theologies that are liberative will require a lot of courage, as it will challenge Public theologians to engage with people in the spaces where they live and struggle. It is deeply about active participation in complex processes of land restitution, economic justice, reparation, etc. This approach has the 
possibility to slowly but surely restore trust in the role of Public theologians when they are willing to engage with complex issues, with credibility and respect.

This contribution has argued that Public theologians should and can become a prominent player, together with others to engage with the perspectives of decolonisation, deimperialisation and incommensurability in order to develop sustainable peace and reconciliation. Within this context, this contribution has attempted to provide some recommendation for Public theologians to engage with these challenges in their endeavour to be advocates for sustainable peace and reconciliation. I shall conclude with the words of the Nobel Peace laureate Dr Mohammed ElBaradei (2015:11) who ended his address with a plea to rebuild international structures of cooperation, conflict prevention and humanitarian and development aid, stating 'We either swim together, or sink together'.

\section{Acknowledgements \\ Competing interests}

The author declares that he has no financial or personal relationships which may have inappropriately influenced him in writing this article.

\section{References}

Collins English Dictionary, 2016, Collinsdictionary.com, viewed 30 July 2016, from https://www.collinsdictionary.com/dictionary/english.

ElBaradei, M., 2015, 'War and peace', in Opening lecture presented at the International Conference on The Economics of War and Peace, International Center of Economics in Society, University of Zurich, Kaufleuten Zurich, November 16, viewed 16 June 2016, from http://www.ubscenter.uzh.ch/assets/newsletter/2015-12/files/assets/ 2016, from http://www.
basic-html/page-11.html\#

Gaylard, G., 2005, After colonialism. African postmodernism and magical realism, Wits University Press, Johannesburg.

Hofmeyr, J. \& Govender, R., 2015, National reconciliation, race relations, and social inclusion, SA Reconciliation Barometer, IJR, Cape Town.

Jansen, J., 2015, Racism on campus: Jumping around 'like Mad Hatters', viewed 22 June 2016, from http://www.thejournalist.org.za/spotlight/racism-jump-aroundlike-mad-hatters
Makgoba, T., 2016, 'Rebuilding South Africa, recovering our vision and renewing our society', in Opening Remarks During the Launch of a National Conversation on the Socio-Economic Future of South Africa, Friday, March 11, viewed 16 April 2016, http://archbishop.anglicanchurchsa.org/2016/03/rebuilding-south-africarecovering-our.html

Mbembe, A., 2015, Decolonizing knowledge and the question of the archive, viewed 30 May 2016, from http://wiser.wits.ac.za/system/files/Achille $\% 20$ Mbembe $\% 20$ $\% 20$ Decolonizing $\% 20$ Knowledge $\% 20$ and $\% 20$ the $\% 20$ Question $\% 20$ of $\% 20$ the $\% 20$ Archive.pdf.

Mbembe, A., 2016, The State of South African political life, viewed 30 May 2016, from Africaisacountryhttp://africasacountry.com/2015/09/achille-mbembe-on-thestate-of-south-african-politics/2016/04/16

Msimang, S., 2015, The old is dying and the young ones have just been born. Africa is a country, viewed 16 April 2016, from http://africasacountry.com/2015/05/theold-is-dying-and-the-young-ones-have-just-been-born/

Msomi, S. \& Shilaho, W., 2008, Racism still a threat to South Africa's democracy, Centre for the Study of Violence and Reconciliation, viewed 22 June 2016, from http://www.csvr.org.za/index.php/media-articles/latest-csvr-in-themedia/2262-racism-still-a-threat-to-south-africas-democracy.htm

Ndlovu-Gatsheni, S.J., 2013, 'The Entrapment of Africa within the global colonia matrices of power, eurocentrism, coloniality, and deimperialization in the twentyfirst century', Journal of Developing Societies 29(4), 331-353. https://doi. org/10.1177/0169796X13503195

Ndlovu-Gatsheni, S.J., 2014, 'Eurocentrism, coloniality, and the myths of decolonisation of Africa', The Thinker 59, 34-39.

Nyamnjoh, F.B., 2016, 'Sir Cecil John Rhodes: In Plaatjies', in D.C. Hongoro, M. ChitigaMabugu, T. Meyiwa, M. Nkondo \& F. Nyamnjoh (eds.), State of the Nation. Who is in charge? Mandates, accountability and contestations in South Africa, pp. 1-64, (Mrt., 2016), The Makwerekwere with a missionary zeal, HSRC Press, Pretoria.

Pakenham, T., 1991, The scramble for Africa, Jonathan Ball Publishers, Johannesburg.

Pollyfeyt, D., 1996, 'Het onvergeeflijke vergeven? Een etische analyse van kwaad en verzoening', in R. Burggraeve \& J. De Tavernier (eds.), Terugkeer van de wraak? pp. 155-178, Gooi en Sticht, Averbode.

Smit, D.J., 2008, Opstelle oor geloof en die openbare lewe. Versamelde opstelle 2, Sun Press, Stellenbosch.

Snyman, D., 2014a, A report on the work of the Restitution Foundation for the period January 2013 to March 2014, Restitution Foundation, Cape Town, viewed 26 April 2015, from http://www.restitution.org.za/wp-content/uploads/RestitutionFoundation-2013-2014-Report.pdf

Snyman, D., 2014b, 'Reconciliation within a local context', in C.H. Thesnaar (ed.), Symposium on the Challenges of Reconciliation in a Post TRC South Africa, Unpublished report, Stellenbosch University, Stellenbosch, South Africa, February 11-12, pp. 5-7.

Truth and Reconciliation Commission (TRC), 1998, Truth \& reconciliation Commission Report, vols. 1, 4 \& 5, Truth and Reconciliation Commission, Cape Town.

Talane, V., 2012, South Africa's 'born-frees' come of age, viewed 30 May 2016, from http://www.southafrica.info/about/people/born-free-260412.htm\#.VOwvIE1-PtQ

Tuck, E. \& Yang, K., 2012, 'Decolonization is not a metaphor', Declination: Idigeneity, Education \& Society 1(1), 1-140.

Van der Borght, E., 2015, 'Reconciliation in the public domain. The South African case', InternationalJournalofPublic Theology9,412-427.https://doi.org/10.1163/1569732012341414

Wa Said, D., 1971, 'An African theology of decolonization', The Harvard Theological Review 64(4), 501-524. https://doi.org/10.1017/S0017816000023415 